\title{
Electron Microscopic Study of the Nuclei in a Sorangium species
}

\author{
By A. A. IMSHENETSKY AND V. V. ALFEROV \\ Institute of Microbiology, U.S.S.R. Academy of Sciences, Moscow
}

(Received 4 April 1961)

\begin{abstract}
SUMMARY
Electron microscopy of ultrathin sections enabled the fine structural peculiarities of a myxobacterium (Sorangium sp.) to be studied. The myxobacteria did not show the dense membrane characteristic of eubacterial cells. A very thin membrane in the myxobacteria cells was not distinguishable from the cytoplasm. In ultrathin sections of the myxobacteria there was observed a broad dark coloured cytoplasmic layer, a light meshlike nuclear vacuole located in the centre of the cell and a rather large nucleus situated in the vacuole; the nucleus displayed density, dark colour and roundness. The elongated myxobacteria cells may include two to three nuclei. Phase-contrast microscopy of living unstained organisms of the Sorangium sp. studied revealed large rounded nuclei. The observations of living cells permitted the amitotic division of nuclei which precedes cell division in myxobacteria to be studied. The studies of the ultrathin sections with the aid of electron microscopy and the microscopy of the living cells supply similar data about the fine structure of the myxobacterial cells. The structure of the myxobacterial cells is more complicated than in the Eubacteria. The peculiar life cycle and the existence of a large nucleus easily detectable (by various methods) enables one to place the myxobacteria among the relatively highly organized micro-organisms.
\end{abstract}

\section{INTRODUCTION}

Fine detail in the structure of true bacteria (Eubacteriales) continues to be a subject of lively argument (DeLamater, 1960; Bissett, 1952). On the other hand, the study of the structure of the myxobacterial cell usually led to rather close agreement. Seventy years have elapsed since the appearance of Thaxter's (1892) classical work which described the Myxobacteriales for the first time. All those who have been engaged in the study of cell structure in myxobacteria since then have continually observed rather large and easily distinguishable nuclei, differentiated morphologically from cytoplasm and demonstrated without any difficulty by the common cytological methods.

Beebe (1941), Klieneberger-Nobel (1947), Loebeck \& Ordal (1957) studied the cytology of myxococci in detail and Grace (1951) that of the Sporocytophaga. In spite of some disagreement in interpretation of microscopic pictures, nuclei were distinguished in all cases with the myxobacteria. Under the electron microscope it was shown that nuclei of myxococci may appear dark or light, though it is remarkable that in fixed cells it was impossible to detect the dark nuclei (Loebeck \& Ordal, 1957). However, in the course of studying the biology of myxobacteria it became evident that bacteria not forming fruiting bodies and exhibiting a reduced life cycle 
belonged to the same group and these were named Promyxobacteria (Imshenetsky $\&$ Solntzeva, 1945). The peculiar feature of these more primitive forms is that some species contain deoxyribonucleic acid, but are devoid of a morphologically discrete nucleus. The representatives of the genus Cytophaga, which include species which decompose cellulose and species devoid of this capacity (Stanier, 1942; Imshenetsky $\&$ Solntzeva, 1936) may be grouped with these primitive forms, where a more primitive life cycle corresponds to a simpler cell organization, i.e. one lacking a nucleus. However, the majority of Myxobacteriales consisting of the genera Myxococcus, Melittangium, Sorangium, Polyangium, display large discrete nuclei. By using electron microscope techniques it has been shown for the first time that the nuclei appear denser and darker than the cytoplasm structure (Imshenetsky, 1949). In the present paper the authors give the results of electron microscope studies of ultrathin sections of a species of the genus Sorangium.

\section{METHODS}

The investigation was made on a pure culture of Sorangium sp. isolated from the cellulose mass to be used for paper production. This species was not identified further. When inoculated into Hutchinson's mineral medium (Hutchinson \& Clayton, 1919) it did not decompose filter paper. On the surface of potato agar it formed a round, flat, bright, greyish white colony with a creeping margin (PI. I, fig. 1). The formation of fruiting bodies of macrocysts within the colony was not observed. The rod-like vegetative cells in the older cultures were reduced and converted into oval microcysts, a characteristic feature of the genus Sorangium.

To obtain the necessary amount of myxobacteria the following method was used. A thick watery suspension of myxobacteria taken from a culture which had grown on a slope of potato agar for $18 \mathrm{hr}$. was spread over potato-agar plates. These plates were kept in the incubator at $28^{\circ}$ for $3 \mathrm{hr}$. The newly grown organisms were washed off with a veronal acetate buffer solution $(\mathrm{pH} 7 \cdot 1)$. This suspension was centrifuged and a $1.5 \%(\mathrm{w} / \mathrm{v})$ solution of $\mathrm{KMnO}_{4}$ in distilled water added to the deposited organisms which were then shaken thoroughly and kept for $5 \mathrm{~min}$. at room temperature. After fixation the organisms were washed for $10 \mathrm{~min}$. with tap water and submerged for $2 \mathrm{hr}$. in a $3 \%(\mathrm{v} / \mathrm{v})$ solution of neutral formalin $(40 \%, \mathrm{w} / \mathrm{v}$, formaldehyde). Then the organisms were washed twice with ethanol $(25 \%, v / v)$ in water each time for $30 \mathrm{~min}$. This fixation method provided better results than fixation with osmic acid solution $(0 \cdot 2 \%, w / v)$ or $\mathrm{K}_{2} \mathrm{Cr}_{2} \mathrm{O}_{7}(1 \%, \mathrm{w} / \mathrm{v})$. After fixation, two drops of melted $2 \%(\mathrm{w} / \mathrm{v})$ starvation agar in distilled water were introduced into the bottom of the centrifuge tube containing the deposit of fixed and ethanol-washed organisms. The agar was mixed with the deposit and 1 or 2 drops of this mixture transferred to a sterile glass slide. After cooling, the agar was cut with a scalpel into pieces about 1-2 mm. ${ }^{3}$ each. The pieces were successively treated with $50 \%, 70 \%$, $96 \%(v / v)$ ethanol in water for $15 \mathrm{~min}$. (single changes) and then twice in absolute ethanol for $30 \mathrm{~min}$. Then the agar blocks containing the myxobacteria were placed for $15 \mathrm{~min}$. in a mixture of equal volumes of absolute ethanol and butylmethacrylate, followed by three $15 \mathrm{~min}$. changes in a mixture of $9 \mathrm{vol}$. butyl-methacrylate and 1 vol. methyl-methacrylate. The agar blocks were then placed in gelatin capsules and embedded in a mixture composed of butyl-methacrylate, 
methyl-methacrylate and benzoin $(9 \mathrm{ml} .+1 \mathrm{ml} .+0.05 \mathrm{~g}$.$) . The capsules were closed$ tightly with lids. Polymerization took $8 \mathrm{hr}$. under ultraviolet radiation. Sections were cut with an ultramicrotome which enabled sections $200-300 \AA$ thin to be obtained; these were studied with the aid of a Siemens electron microscope at an acceleration voltage of $45 \mathrm{kV}$.

\section{RESULTS}

\section{The structure of the myxobacterial cell}

It is known that some myxobacteria perform flexible movements which the true bacteria are unable to do. Thus it was of interest to investigate the specific structure of the cell membrane. As expected the cells of the myxobacteria did not show a dense well defined three-layer membrane as seen in representative Eubacteria. Even a magnification of $\times \mathbf{5 0 , 0 0 0}$ did not reveal a darker layer in the peripheral layers of the cytoplasm in myxobacterial cells. This does not mean that the myxobacterial cells are devoid of a thin membrane; the latter may be revealed when the cells of the large myxobacteria are placed in a saturated solution of sodium chloride (Solntzeva, 1941). However, the electron microscope technique did not show this membrane in microphotographs of the Sorangium investigated.

When the section ran parallel with the cell axis, the cell had a cylindrical form with somewhat sharpened ends (Pl. 1, fig. 2). Three zones could be distinguished within the inner part of the cell: (a) The peripheral zone, i.e. the darker zone, corresponding to the rather dense layer of the cytoplasm (Pl. 1, figs. 2, 3, 5). (b) A lighter site displaying a mesh structure in the central part of the cell. This part of the cell seemed to be empty; in it only single net-like structures or fibres set against an entirely light background were visible. This central zone will henceforth be referred to as the nuclear vacuole. (c) As a rule the central part of the nuclear vacuole showed a distinct dense, rounded and well defined nucleus; in the photographs it is almost black (Pl. 1, figs. 2, 3, 5; Pl. 2, fig. 7). In rare cases the nucleus was revealed, not in the central part of the nuclear vacuole, but at its margin (Pl. 1, fig. 4). The size of the nucleus in the ultrathin slice was somewhat smaller, owing to shrinkage during fixation. It should be noted that the apparent size of the nucleus depends upon the plane of sectioning.

The plane of sectioning could affect the cell contour. For example, a lateral sectioning of the cell could be responsible for the cell's apparent spindle-shaped or sphenoid form. Its terminal points could be sharpened (Pl. 1, figs. 3, 4). When the microtome knife cut the cell through the nucleus, the cell's contour displayed a proper rounded form and all the three mentioned zones were observed quite distinctly: the dark broad cytoplasmic ring which exhibited minute grain structure, a slightly oval-shaped light nuclear vacuole and a dark round nucleus (Pl. 2, fig. 6). In small cells, as a rule, there was only one nucleus. However, the division of the nucleus may occur much earlier than cell fission; the typical pattern of the latter in myxobacteria was transverse binary fission. In this case the elongated cell showed 2-3 nuclei located at a considerable distance from each other (Pl. 2, figs. 7, 8). Sometimes, the section ran through the cell above or below the nucleus and then the photographs showed cells containing only cytoplasm and the nuclear vacuole, but devoid of the dark round nucleus (see Pl. 1, fig. 3; Pl. 2, figs. 7, 8).

The comparative study of the electron micrographs with microphotographs of 
living unstained Sorangium cells is of interest. Phase-contrast microscopy in living cells revealed the nuclei most distinctly (Pl. 2, figs. 9, 10). In living myxobacteria the nuclei appeared larger than the cell nuclei observed in the ultrathin sections. This may be attributed to shrinkage of the nuclei under conditions of 'severe' fixation and the treatment which the cells received before the ultrathin sectioning.

The observation of living myxobacteria enabled the cell division pattern by segmentation which took place before cell division by fission to be traced. Similar dividing cells are marked with arrows in Pl. 2, figs. 9 and 10. In living cells as well as in the ultrathin cell sections two nuclei were sometimes seen. Similar cells are represented in Pl. 2, fig. 9, and are marked as ' $\mathrm{D}$ '. The microscopy of living young Sorangium cells revealed a lighter, rather wide zone surrounding the nucleus; this zone may possibly correspond to the nuclear vacuole observed in the ultrathin sections. These light passages were especially well seen at the end of the lag phase. i.e. 3-4 hr. after the re-inoculation of the culture on to fresh nutrient medium. The results of studying the structure in living Sorangium cells will be presented in a separate paper.

\section{DISCUSSION}

Both electron microscopy of ultrathin sections and phase-contrast microscopy of living cells gave identical results for the investigation of nuclei in myxobacteria. The form, localization and behaviour of the nuclei turned out to be of analogous character. From the viewpoint of comparative cytology it should be noted that electron microscope techniques revealed that in myxobacteria the nuclei appeared to be much denser than the cytoplasm and, similar to the picture shown in plant and animal cells, they were much darker than the cytoplasm. The high content of deoxyribonucleic acid in the myxobacteria (Belozersky, 1959) is in agreement with the presence of rather large nuclei. The physico-chemical features of this nuclear structure would explain the retardation of the electron beam and hence the appearance of dense dark nuclear structures in the microphotographs of ultrathin sections. It should be emphasized that electron microscopy of true bacteria (Eubacteriales) does not reveal similar dark structures and the nuclear vacuoles are often described as the nucleus, shown as large light sites located in the central part of the cell. The division of nuclei in myxobacteria follows an amitotic pattern and usually precedes the cell division process.

The myxobacterial nuclei observed in unstained living organisms shows that phylogenetically this group is much higher than the true bacteria (Eubacteriales). Study of the detailed karyologic characteristics of the myxobacteria is a task for future investigations, but even at present it is evident that the complex life cycle of the myxobacteria, the formation of fruiting bodies in particular, harmonizes with the complicated organization of the organism itself. Therefore it is hard to agree with the suggestion that the myxobacteria and the eubacteria, particularly the sporogenous bacilli, have an identical nuclear apparatus (Badian, 1933). The polyphyletic origin of bacteria is indisputable and amongst them it is possible to distinguish both more and less complicated organisms. 

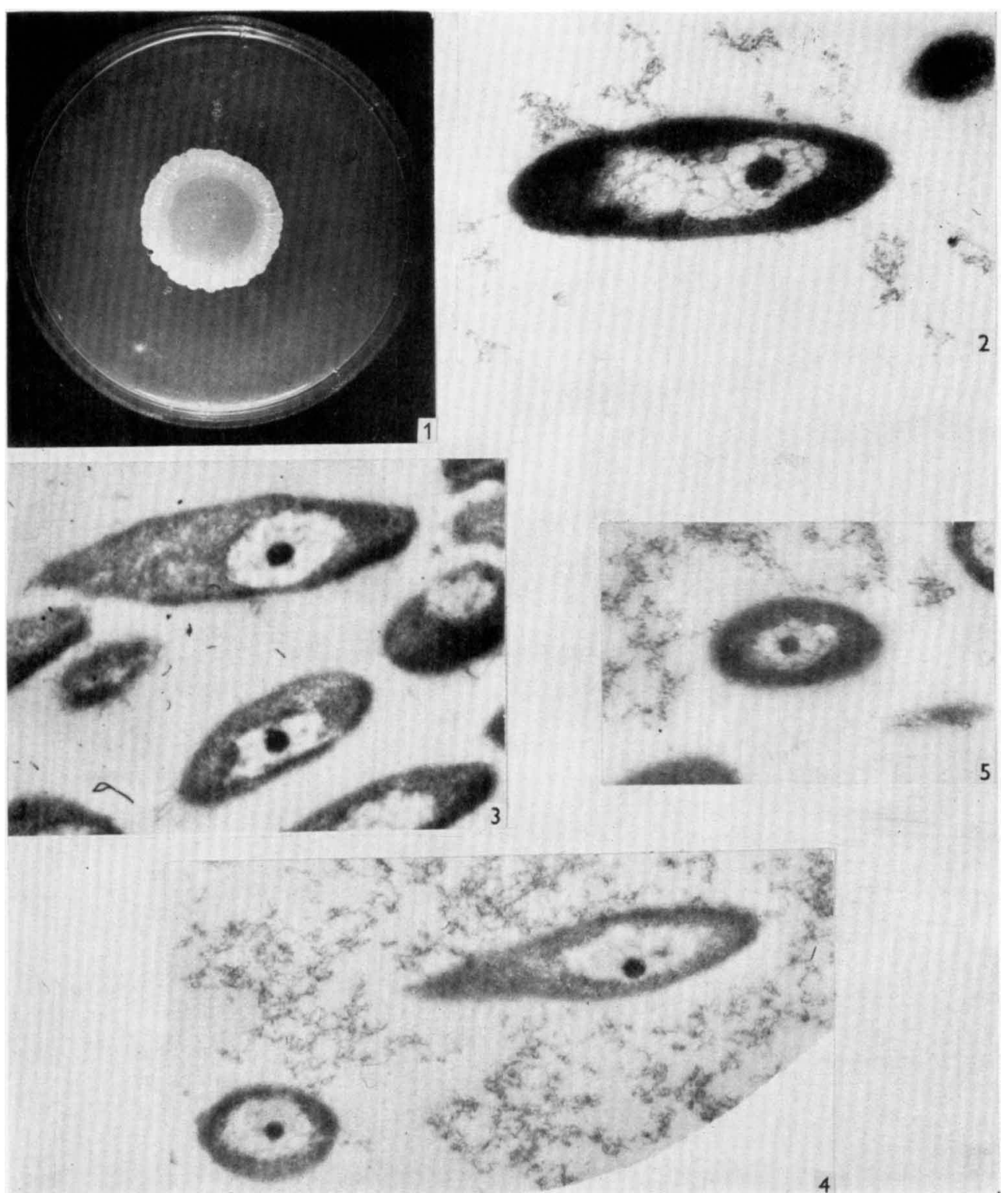


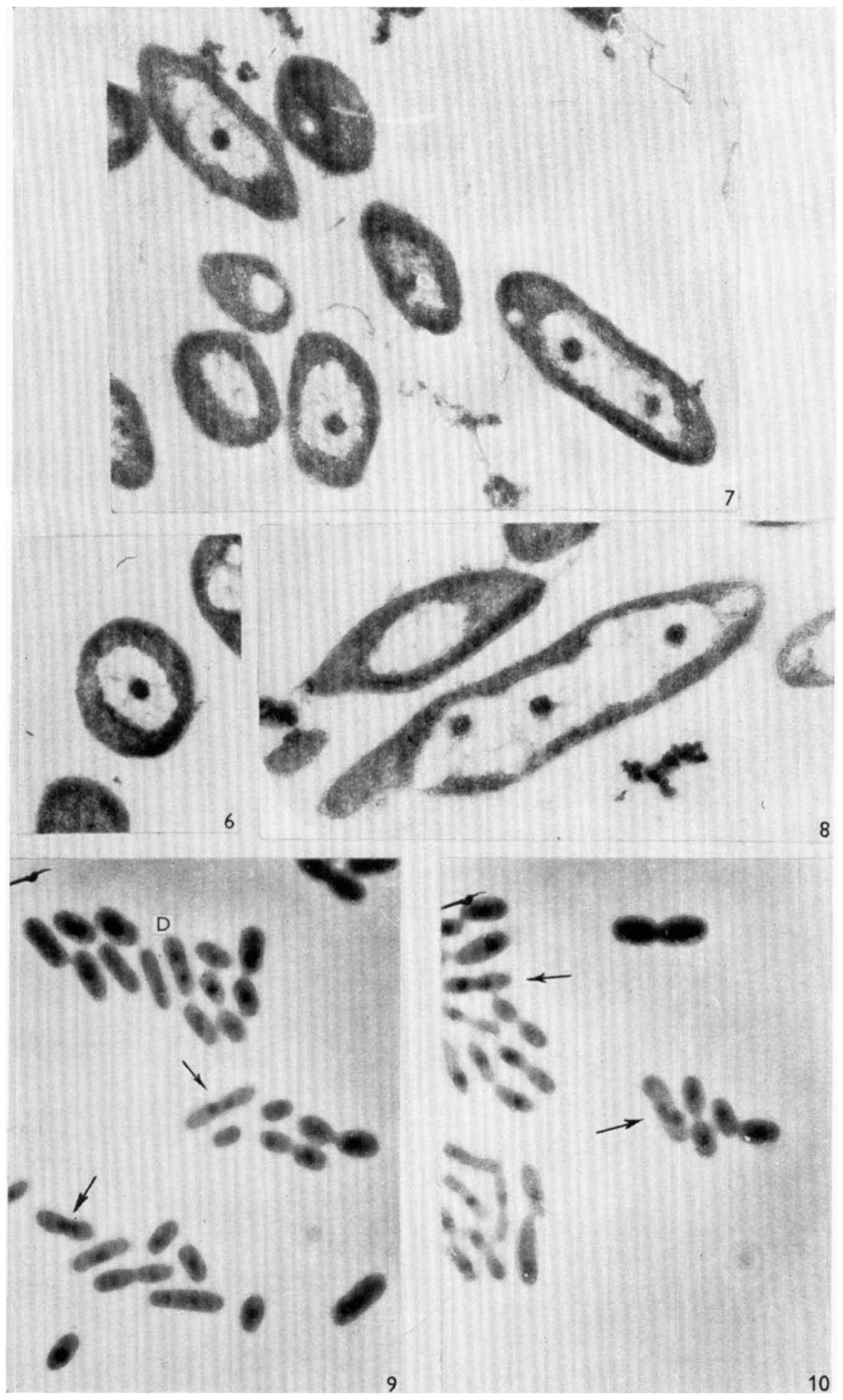

A. A. IMSHENETSKY AND V. V. ALFEROV 


\section{REFERENCES}

Badian, J. (1933). Eine cytologische Untersuchung über das Chromatin und den Entwicklungszyklus der Bakterien. Arch. Mikrobiol. 4, 409.

BeEbe, J. (1941). The morphology and cytology of Myxococcus xanthus, n.sp. J. Bact. 42, 193.

Belozersky, A. (1959). Nucleoproteidi $i$ nucleinovie kisloti rastenij ikh biologicheskoje znachenije. Moskva.

BIsset, K. (1952). The interpretation of appearances in cytological staining of bacteria. Exp. Cell Res. 3, 681.

DeLamater, E. (1960). Chromosomi bacterij i mekhanism ikh delenija. Anatomija bacterij. Moskva.

Grace, J. (1951). The life cycle of Sporocytophaga. J. gen. Microbiol. 5, 519.

Hutchinson, H. \& Clayton, I. (1919). On the decomposition on cellulose by an aerobic organism (Spirochaeta cytophaga, n.sp.). J. agric. Sci. 9, 141.

IMSHENETSKy, A. (1949). Electronnomicroscopichescoye isuchenye micsobacteriy. Microbiology, Moscow, 18, 393.

Imshenetsky, A. \& Solntzewa, L. (1936). Ob aerobnikh cellulosnikh bacteriyakh. Bull. Acad. Sci. U.R.S.S. (Sér. Biol.), 6, 1115.

Imshenetsky, A. \& Solntzewa, L. (1945). O nesowershenikh formakh micsobacteriy. Microbiology, Moscow, 14, 22.

Klieneberger-Nobel E. (1947). A cytological study of Myxococci. J. gen. Microbiol. $1,33$.

LoEbeck, M. \& Ordal E. (1957). The nuclear cycle of Myxococcus fulvus. J. gen. Microbiol. 16, 76.

Solntzewa, L. (1941). Biologiya micsobacteriy. II. Rod Melittangium i rod Chondromyces. Microbiology, Moscow, 5, 505.

Stanier, R. (1942). The Cytophaga group: a contribution to the biology of myxobacteria. Bact. Rev. 6, 143.

Thaxter, R. (1892). On the Myxobacteriaceae, a new order of Schizomycetes. Bot. Gaz. 17, 389.

EXPLANATION OF PLATES

Plate 1

Fig. 1. A giant colony of Sorangium sp. in the Petri dish of potato agar.

Fig. 2. An ultrathin section of the Sorangium sp. cell cut in parallel with the cell's long axis. The cytoplasm, light nuclear vacuole and the dark nucleus are visible. The cell's thin membrane is not discernible $(\times \mathbf{5 0 , 0 0 0})$.

Fig. 3. The oblique ultrathin section reveals a spindle-like cell contour. The sections reveal the nuclei, a nuclear vacuole, and dark cytoplasm $(\times 40,000)$.

Fig. 4. As a result of oblique sectioning the cell displays a sharpened end $(\times 40,000)$.

Fig. 5. The sectioning of a small-sized juvenile cell. A dark cytoplasm and nucleus. Light nuclear vacuole $(\times 40,000)$.

Plate 2

Fig. 6. A transverse section of the rod-like Sorangium sp. cell. A light nuclear vacuole with a nucleus in the centre. The vacuole is surrounded with a dark cytoplasmic ring $(\times 40,000)$.

Fig. 7. Two nuclei in the elongated Sorangium sp. cell. In some cells the nuclei are not seen because the section was either above or below the nucleus $(\times 40,000)$.

Fig. 8. Three nuclei are located in the light nuclear vacuole of the elongated Myxobacteria cell. In the second cell the section is either above or below the nucleus, which is therefore not seen in the cell $(\times 40,000)$.

Fig. 9. The living non-stained Sorangium sp. cells. The arrow marks cells containing the dividing nucleus. Letter ' $D$ ' denotes cells having two nuclei. Phase contrast $(\times 4500)$.

Fig. 10. Nuclei in the living Myxobacteria cells. Cells with dividing or recently divided nuclei are marked with arrows. Phase contrast $(\times 4500)$. 